\title{
LQ45 Share Return Determinants In Indonesia
}

\author{
${ }^{1}$ Rahmawan Darsyah, ${ }^{2}$ Hari Sukarno, ${ }^{3}$ Elok Sri Utami \\ ${ }^{1,2,3}$ Faculty of Economics and Business, University of Jember 37 Kalimantan Street, Jember 68132, \\ Indonesia
}

\begin{abstract}
Return is the result obtained from investment. Returns can be in the form of realized returns that haveoccurred or expected returns that have not occurred but are expected to occur in the future. Returnrealization (realized return) is the return that has occurred. Realized return is calculated based on historicaldata. Return realization is important because it is used as a measure of the company's performance. Thisreturn history is also useful as a basis for determining the expected return and risk in the future. Expectedreturn is the return expected by investors in the future. In contrast to realized returns which have alreadyoccurred, expected returns have not yet occurred. The performance measurement was also carried out at theLQ45 company. In general, this study aims to synthesize whether the current ratio, equity ratio, dividendpayout ratio, dividend yield, earnings per share, price book value, return on assets and total asset turnoverare partially determinants of stock return variability. The population in this study were non-bankingcompanies included in the LQ45 according to a circular number: Peng-00028 / BEI.OPP / 01-2018 datedJanuary 25, 2018. Non-bank companies were chosen because the types of products produced were not in theform of services. Hypothesis testing uses multiple linear regression analysis test tools. After analyzing thedata, several conclusions can be drawn, namely: only the current ratio, equity ratio, dividend payout ratio, dividend yield, return on assets and total asset turnover partially determine stock returns.
\end{abstract}

Keywords: Return, LQ45, Financial Ratios, Determinants

\section{Introduction}

The condition of the economy in Indonesia, especially in the era of globalization, has information and data that can be used to make assumptions, causing fundamental changes in the economic sector, including in the investment sector. Basically, economic instability has a lot of negative impacts on society and investors. The negative impact can be in the form of an estimated inflation that cannot be guaranteed so that production costs tend to increase. For companies with economic instability, funding sources from outside the company are difficult to obtain because the guarantee of return on capital and profits is getting smaller.

Financial analysis seeks to identify the financial strengths and weaknesses of a company in order to provide an important basis for making decisions related to financial performance. Financial performance is an analysis carried out to see the extent to which a company has implemented proper and correct financial implementation rules. Company performance is a description of the financial condition of a company that is analyzed using financial analysis tools, so that it can be seen about the good and bad financial condition of a company that reflects work performance in a certain period (According to Fahmi, 2015: 2). In financial analysis, this ratio is used as a yardstick for evaluating a company in the past, present and future to help investors make decisions about buying, selling or holding certain assets. The main objective of investors is to maximize their returns temporarily but attempts to reduce risk. The company's financial ratios that can be measured consist of current ratio, debt to equity ratio, dividend payout ratio, dividend yield, earning per share, price book value, price earning ratio, return on assets, and total asset turnover (Kasmir, 2016: 106 ).

Current Ratio, or current ratio, is a common measure used for short-term solvency and the ability of a company to meet debt needs when it matures (Fahmi, 2015: 139). The current ratio is a ratio used to measure a company's ability to pay its short-term liabilities by using its current assets 
(Sujarweni, 2017: 60). The current ratio is a ratio to measure the company's ability to pay short-term obligations or debts that are due immediately when they are collected as a whole (Kasmir, 2016: 134).

Debt To Equity Ratio, is a comparison between debt and equity in company funding and shows the company's own capital ability to fulfill all of its obligations (Sujarweni, 2017: 61). Dividend Payout Ratio, is a ratio that shows the comparison between cash dividends per share and earnings per share (Kasmir, 2016: 107). The amount of dividends distributed to shareholders is determined by a percentage known as the "Dividend Payout Ratio".

Dividend Yield is an indicator that can affect stock return, which is the percentage of profit per share divided by the market price per share received by the company (Kasmir, 2016: 109). A high dividend yield indicates that a capital market is undervalued, that is, if the stock market price is less than its value, then the shares must be bought and held temporarily (buy and hold) with the aim of obtaining capital gains if the price then rises again.

Earning Per Share, is a form of giving benefits to shareholders from each share they own (Fahmi, 2015: 138). Price Book Value, is the ratio used by consultants, financial managers, and investors to compare a company's market value (market capitalization) to its book value (shareholder equity). Price to book value is expressed as a multiple of the market value of the investment in the company at its cost.

Price Earning Ratio, shows the comparison between the market share price or the initial price offered compared to the income received (Harahap, 2015). Price Earning Ratio is a ratio that compares the market price per share (market price share) to earnings per share (earnings per share). This ratio is often used to compare investment opportunities. By knowing the amount of a company's Price Earning Ratio, investors can estimate the position of a stock relative to other stocks, whether the stock is worth buying or not (Bringham and Houston, 2012: 98).

Return on assets, is used to measure the effectiveness of the company in generating profits by utilizing its assets. The level of Return On Asset (ROA) depends on the management of the company's assets by management which describes the efficiency of the company's operations. This ratio can be measured by comparing the net profit after tax to total assets (Kasmir, 2016: 112).
Total Asset Turn Over, is used to measure the turnover of all assets owned by the company and measure how many sales were obtained from these assets so that it will be known how much effectiveness the company is in using its resources in the form of assets (Kasmir, 2016: 113). The higher the total asset turnover value, the more effective the company's assets are in generating profits for the company, this is an opportunity for investors to invest and trigger an increase in the company's stock price.

In investing, investors must have a goal, namely to get the return they expect. Return can be divided into two, namely dividends and capital gains (Kasmir, 2016: 113). There are investors who want to get long-term profits by obtaining dividends, so that these investors do not really pay attention to the fluctuations that occur in the capital market but look at the company's financial statements. However, there are also investors who want to get short-term benefits that can be obtained by obtaining capital gains or the difference between the selling price and the purchase price, so that investors who have goals like this always watch for fluctuations in the capital market, because investors will buy stocks or securities. when the price is below and will sell the stock or security when the price has gone up and exceeds the purchase price.

Company value is the company's performance as reflected by the share price formed by the demand and supply of the capital market, which reflects the public's assessment of the company's performance (Harmono, 2014: 233). The value of the company is often associated with the share price. The higher the share price, the higher the value of the company, that maximizing firm value also means maximizing the prosperity of shareholders, which is the company's goal (Septiyuliana, 2016). Firm value can be measured through the value of the share price in the market, based on the formation of the company's share price in the market, which is a reflection of the public's assessment of the company's real financial performance (Harmono, 2014: 50).

According to Jogianto (2011: 38), there are several classifications of share value / price. The nominal value (par value) of a share is the value of the liabilities assigned to each sheet of book value per share showing the net assets owned by shareholders by owning one share. Market value (net value) is the share price of shares on the stock exchange at a certain time which is determined by market participants. The intrinsic value or 
fundamental value is the supposed value of a share. In addition to the price value above, the stock price can also be indicated by the closing price of stock, which is the value of the shares that is emphasized on the company's stock value or stock return.

Return is the result obtained from investment. Returns can be in the form of realized returns that have occurred or expected returns that have not occurred but are expected to occur in the future. Return realization (realized return) is the return that has occurred. Realized return is calculated based on historical data. Return realization is important because it is used as a measure of the company's performance. This return history is also useful as a basis for determining the expected return and risk in the future. Expected return is the return expected by investors in the future. In contrast to realized returns that have already occurred, expected returns have not yet happened (Jogianto, 2011: 107). The performance measurement was also carried out at the LQ45 company.

LQ 45 is a collection of 45 stocks that have high liquidity or are often traded and usually investment managers will place their funds in stocks that are included in LQ45 to reduce liquidity risk. LQ45 is also considered a benchmark for assessing the performance of a capital market based investment (www.google.com). The stocks included in the LQ45 are continuously monitored and will be reviewed every 6 months (early February and August). If there are shares that do not meet the criteria, they will be replaced with other shares that meet the requirements. The selection of LQ45 shares must be reasonable, therefore the IDX has an advisory committee consisting of experts at BAPEPAM, universities and professionals in the field of capital markets

Several researchers have examined the relationship between financial ratios and stock returns. Dimitrich (2016), Septiana and Wahyuati (2016), Wijesundera et al., (2015), Rismansyah (2015), Gunawan and Jati (2013), Nuryana (2013), Farkhan and Ika (2012), Kheradyar et al., (2011) and Hidayat (2010) show that the current ratio, debt to equity ratio, dividend payout ratio, dividend yield, earnings per share, price book value, price earning ratio, return on assets, and total asset turnover have a significant effect on stock returns. Some researchers also found that there is no significant effect of financial ratios on stock returns. Hadiningrat, et al (2017), Wardana, et al (2015), as well as Kusumo and Mutmainah (2010) in their research show that financial ratios have no significant effect on stock returns.

The existence of this research gap is a separate gap for researchers to re-examine the financial ratios of LQ 45 companies. The inconsistencies shown make researchers want to review financial ratios to stock returns using the latest data. Researchers are interested in proving that whether there is an effect of the selected financial ratios on stock returns in LQ 45 companies. Based on the background presented, it is found that there is a problematic inconsistency in the results of research on what factors determine the fluctuating variations of stock returns of non-bank issuers. Therefore, through this research a research question is asked: whether the current ratio, equity ratio, dividend payout ratio, dividend yield, earnings per share, price book value, return on assets and total asset turnover are partially determinants of variability. stock returns?

\section{Literature Review}

Current Ratio (CR) is a way to test the level of protection obtained by short-term lenders provided by companies to fund the company's operational activities. CR has a positive and significant effect on the value of stock returns. The effect of CR on stock returns, namely if the CR is low it will cause a decrease in stock returns, and if the CR is too high it is considered not good, because in certain conditions it shows that many company funds are unemployed (little activity) which in turn can reduce the company's profit. For this reason, the company must maintain an optimal CR, namely CR which shows the size of the company's ability to meet its operational needs, especially working capital which is very important to maintain company performance which in turn affects stock return performance. This can give confidence to investors to own the company's shares so as to increase stock returns.

Debt Equity Ratio (DER) is an attempt to show the relative proportion of lenders to ownership rights, and is used as a measure of the role of debt. The empirical study of the relationship between DER and stock returns is described as a significant relationship to the value of stock returns. The higher the DER, the greater the dependence of the company on outsiders so that the level of company risk is greater in meeting its debts, namely paying the principal of debt plus the interest. This has an impact on the decline in stock prices and stock returns, so that investors are not 
responsive to this information in making investment decisions on stocks.

Dividend Payout Ratio (DPR) is a comparison between dividend per share and earnings per share (Ang, 2010). Companies that have a high DPR naturally cause the value of their share prices to increase because investors have better certainty about dividend distribution on their investments. This increase also boosted the amount of demand for these shares, which also increased share prices and resulted in a positive return (Amarjit, 2010).

Dividend Yield (DY) is the percentage result of profit per share divided by the price per share received by the company. The height of a DY indicates that a capital market is in an undervalued state, that is, if the stock market price is less than its fair value, the shares must be bought and temporarily held, with the aim of obtaining capital gains if the price starts to rise. The strength that DY can predict comes from the role of dividend policy in distributing the returns that the company receives to shareholders.

Earning Per Share (EPS) describes the amount of rupiah earned for each common share. According to Tandelilin (2011: 241). Prospective shareholders are interested in large earnings per share, because a large value of earnings per share is one of the indicators of a company's success, which causes the company's value to increase, which means that the company's stock price is high. So the factor of earnings per share (EPS) or earnings per share of the company has a strong influence on return. The greater the value of earnings per share owned by the company, the more profitable it will be for its shareholders, besides that it means that the company is also able to generate large amounts of profit.

Price Book Value (PBV) provides an overview of the potential price movements of a share. The point is, if a stock with good performance turns out to have a low PBV compared to the average $\mathrm{PBV}$ of shares in its sector, the stock price still has the potential to increase and vice versa (Tryfino, 2009: 11). The relationship between stock market prices and book value per share can also be used as an alternative approach to determining the value of a share, because theoretically, the stock market value must reflect its book value (Tandelilin, 2011: 323).

Price Earning Ratio indicates the amount of rupiah that must be paid by investors to get one rupiah of company earnings (Tandelilin, 2011: 243). In other words, the price earning ratio shows the price per one rupiah earnings of the company. So the price earning ratio (PER) is the ratio between the share price and the profit of each share. The lower the price earning ratio, it can be said that a stock is good as an investment choice. Meanwhile, the higher the price earning ratio indicates that the ratio of share price to the ability to earn profits is not appropriate. A lower PER ratio can cause the company's stock price to increase, which means that the return will also increase, and vice versa.

Return on assets shows the company's ability to generate profits from the assets used (Sartono, 2011: 131). So return on assets (ROA) is a ratio that describes the profit that can be obtained by the company from its assets. The higher the value of return on assets, it shows that the capital invested by the company in all its assets produces a higher net profit. Conversely, if the value of return on assets is small, it means that the investment made by the company in its assets is less profitable. So the higher this ratio indicates the efficiency of asset management, which means management efficiency.

TATO (Total Asset Turnover) is a ratio used to measure how efficiently all company assets are used to support sales activities by comparing sales to total assets. If sales are greater than total assets, the rate of return on profits or returns obtained by the company will be high, because large sales reflect large profits for the company. Conversely, if the total assets are higher than the sale, the return will be low.

Kusumo and Mutmainah (2010) found that the financial ratios on ROA, DER, CR did not have a significant effect on stock returns. Hidayat (2010) found that the liquidity ratio, solvency ratio and activity ratio did not have a significant effect on stock returns, while the profitability ratio and market / valuation ratios had a significant effect on stock returns. Simultaneously shows that financial ratios have a positive effect on stock returns. Kheradyar et al., (2011), found that financial ratios can increase the predictability of stock returns when the ratios are combined in several predictive regression models. Farkhan and Ika (2012) found that Return On Assets (ROA) and Price Earning Ratio (PER) had a significant effect (on stock returns. As for the other variables CR, DER, and TAT did not have a significant effect on stock returns, because they have alpha value is greater than 0.05 or 5\%. Nuryana (2013), found that ROI (Return On Investment), DER (Debt Equity Ratio), TATO (Total Asset Turn Over), EPS (Equity Per Share), GPM ( Gross Protif Margin), two (2) have a positive sign and 
three (3) have a negative sign that affects stock returns. Gunawan and Jati (2013) found that there is no significant effect of the NPM, ROA and ROE variables on stock returns. There is a partially significant effect of EPS and PER variables on stock returns. Rismansyah (2015), found that current ratio, debt equity ratio, and return on assets have no effect on stock returns, while total asset turnover and price book value have an effect on stock returns. a significant to stock returns. Wijesundera et al., (2015), found that ROE, EPS and MV / BV have a significant positive relationship with stock returns followed by a simple equation to predict future stock returns. Wardana, et al (2015) found that PER has an effect on abnormal returns, while NPM, PBV and CR have no effect on abnormal returns. Septiana and Wahyuati (2016) found that partially showing debt equity ratio, current ratio has a significant effect on stock returns, while return on assets, total asset turnover and price earning ratio have no significant effect on stock returns. Debt Equity Ratio has a dominant influence on stock returns with the largest coefficient of determination of $15 \%$.

\section{Methodology}

This design is included in explanatory research, which is research that tries to explain a problem and there is a hypothesis testing and analysis of the data obtained. The population in this study were non-banking companies included in the LQ45 according to a circular number: Peng-00028 / BEI.OPP / 01-2018 dated January 25, 2018. Sampling in this study was carried out using purposive sampling method where the number of respondents in This study included 39 nonbanking companies that are members of the LQ45 according to the circular number: Peng-00028 / BEI.OPP / 01-2018 dated January 25, 2018. Nonbank companies were selected because the types of products produced were not in the form of services.

\section{Results and Discussion}

\subsection{Results}

The LQ-45 index is not intended to replace the existing JCI, but rather as a complement to the JCI and sectoral indices. The LQ-45 Index aims to provide objective and reliable advice for financial analysts, investment managers, investors and other capital market observers in monitoring the price movements of actively traded stocks. Investment portfolios in LQ-45 stocks tend to be profitable if market conditions improve, with a sensitive nature to market changes, they will enjoy profits first, on the other hand, if the market tends to decline, the stock price tends to fall first compared to other stocks. The increase or decrease in stock prices in LQ-45 will be influenced by the increase or decrease in the IHSG.

Table 1. List of companies included in the calculation of the LQ-45 index during 2013-2017

\begin{tabular}{|c|c|c|c|c|c|}
\hline \multicolumn{7}{|c|}{$\mathbf{2 0 1 3 - 2 0 1 7}$ period } \\
\hline No & Securities Code & No & Kode Efek & No & $\begin{array}{c}\text { Securities } \\
\text { Code }\end{array}$ \\
\hline 1 & AAL1 & 16 & ELSA & 31 & PGAS \\
\hline 2 & ADHI & 17 & EXCL & 32 & PPRO \\
\hline 3 & ADRO & 18 & GGRM & 33 & PTBA \\
\hline 4 & AKRA & 19 & HMSP & 34 & PTPP \\
\hline 5 & ANTM & 20 & ICBP & 35 & PWON \\
\hline 6 & ASII & 21 & INCO & 36 & SCMA \\
\hline 7 & ASRI & 22 & INDF & 37 & SMGR \\
\hline 8 & BBCA & 23 & INTP & 38 & SMRA \\
\hline 9 & BBNI & 24 & JSMR & 39 & ARIL \\
\hline 10 & BBRI & 25 & KLBF & 40 & SSMS \\
\hline 11 & BBTN & 26 & LPKR & 41 & TLKM \\
\hline 12 & BMRI & 27 & LPPF & 42 & UNTR \\
\hline 13 & BSDE & 28 & LSIP & 43 & UNVR \\
\hline 14 & BUMI & 29 & MNCN & 44 & WIKA \\
\hline 15 & CPIN & 30 & MYRX & 45 & WSKT \\
\hline
\end{tabular}


Sumber: $w w w . j s x . c o . i d$

hares that will be included in the calculation are only non-banking companies, because the type of product produced is not a service company. The companies collected are as many as 40 companies. Regression analysis is related to the study of the dependence of a dependent variable on one or more independent variables in order to determine the determinant of each independent variable on the dependent variable. The results of the regression analysis for equation 3.1 can be seen in Table 2.

Table 2 Summary Results of Multiple Linear Regression Analysis Equation 3.1

Source: Processed Data. 2020

\begin{tabular}{|c|c|c|c|}
\hline Variable & $\begin{array}{c}\text { Stand. } \\
\text { Coefficients }(\beta)\end{array}$ & Tvalue & Information \\
\hline (Constant) & 0,141 & & \\
DER & 0,108 & 3,518 & Significant \\
DPR & 0,075 & 2,868 & Significant \\
DY & $-0,099$ & $-3,004$ & Significant \\
EPS & 0,047 & 1,659 & Not significant \\
PBV & 0,045 & 1,672 & Not significant \\
PER & 0,131 & 2,573 & Significant \\
ROA & 0,075 & 2,756 & Significant \\
TATO & 0,689 & 15,597 & Significant \\
\hline
\end{tabular}

Information $: \mathrm{t}_{\text {table }}=1,971$

Rsquare : 0,800

The regression model based on the results of the above analysis is:

Return=0,141+0,108DER+0,075DPR0,099DY+0,047EPS+0,045PBV+0,131PER+0,075RO A $+0,689$ TATO

In accordance with the regression line equation obtained, the regression model can be interpreted as follows:

1. $\beta_{0}=1,41$

The constant coefficient value indicates that if there is no change in the variable DER,DPR,DY,EPS,PBV,PER,ROA dan TATO or $\left\{X_{1}, X_{2}, X_{3}, X_{4}, X_{5}, X_{6}, X_{7}, X_{8}=0\right\}$, then Return $(\mathrm{Y})$ amounting to 0,141 .

2. $\beta_{1}=0,108$

Regression coefficient value $\beta_{1}$ indicates that if the variable value DER has increased by $1 \%$ and other independent variables are assumed to be constant, then the rate of return will increase by 0,108 .

3. $\beta_{2}=0,075$

Regression coefficient value $\beta_{2}$ giving meaning that, an increase in value of $1 \%$ in the DPR variable, while other independent variables are assumed to be constant, the Return will increase by 0,075 .

4. $\beta_{3}=-0,099$

Regression coefficient value $\beta_{3}$ gives meaning that, an increase in value of $1 \%$ in the DY variable, while the other independent variables are assumed to be constant, the Return will decrease by 0,099 .

5. $\beta_{4}=0,047$

Regression coefficient value $\beta_{4}$ memberi makna bahwa, kenaikan nilai sebesar $1 \%$ pada variabel EPS, sementara variabel independen lainnya diasumsikan konstan, maka Return akan meningkat sebesar 0,047 .

6. $\beta_{5}=0,045$

Regression coefficient value $\beta_{5}$ means that, an increase in value of $1 \%$ in the EPS variable, while the other independent variables are assumed to be constant, the Return will increase by 0,045 .

7. $\beta_{6}=0,131$

Regression coefficient value $\beta_{6}$ means that, the increase in value of $1 \%$ in the PER variable, while other independent variables are assumed to be constant, the Return will increase by 0,131 .

8. $\mathrm{B}_{7}=0,075$

Regression coefficient value $\beta_{7}$ gives meaning that, an increase in value of $1 \%$ in the ROA variable, while other independent variables are assumed to be constant, the Return will increase by 0,075 .

9. $\beta_{6}=0,689$

Regression coefficient value $\beta_{8}$ means that, an increase in value of $1 \%$ in the TATO variable, while other independent variables are assumed to be constant, the Return will increase by 0,689 . 
The results of the analysis show the coefficient of determination or $\mathrm{R} 2=0.800$. This value shows together the variables DER, DPR, DY, EPS, PBV, PER, ROA and TATO have an effect on Return of $80 \%$. In other words, the $80 \%$ change in Return can be explained by DER, DPR, DY, EPS, PBV, PER, ROA and TATO. Testing the regression coefficient value of each independent variable can be done by comparing the arithmetic statistic and table statistic, if tcount $>$ ttable it can be said that there is a significant effect of the independent variable on the dependent variable.

The research hypothesis testing aims to determine whether the current ratio, equity ratio, dividend payout ratio, dividend yield, earnings per share, price book value, return on assets and total asset turnover partially determine stock returns. The results of the $t$ test in equation 3.1 are as follows:

Table 3. Summary Results of the $t$ test in Equation 3.1

\begin{tabular}{|l|c|c|c|}
\hline \multicolumn{1}{|c|}{ Variabel } & $\mathrm{T}_{\text {value }}$ & $\mathrm{t}_{\text {table }}$ & Information \\
\hline Variabel Independen: & & & \\
Return & & & \\
Variabel Dependen: & & & \\
DER & 3,518 & 1,971 & Significant \\
DPR & 2,868 & 1,971 & Significant \\
DY & $-3,004$ & 1,971 & Significant \\
EPS & 1,659 & 1,971 & Not significant \\
PBV & 1,672 & 1,971 & Not significant \\
PER & 2,573 & 1,971 & Significant \\
ROA & 2,756 & 1,971 & Significant \\
TATO & 15,597 & 1,971 & Significant \\
\hline
\end{tabular}

Source: Processed Data. Annex 3. 2020

There are 2 variables, namely EPS and PBV with tcount <ttable, so that only the current ratio, equity ratio, dividend payout ratio, dividend yield, return on assets and total asset turnover partially determine stock returns.Ada 2 variabel yaitu EPS dan PBV yang nilai $t_{\text {hitung }}<$ ttabel, sehingga hanya current ratio, equity ratio, dividend payout ratio, dividend yield, return on asset dan total asset turn over secara parsial menentukan return saham.

\subsection{Discussion}

The analysis results show that the current ratio partially determines stock returns. The higher the current ratio, the better the stock return. If the CR is low, it will cause a decrease in stock returns, and if the CR is too high it is considered not good, because in certain conditions it shows that many LQ45 company funds are unemployed (little activity) which in turn can reduce the profitability of LQ45 companies. For this reason, the LQ45 company must maintain an optimal $\mathrm{CR}$, namely CR which shows the size of the company's ability to meet its operational needs, especially working capital which is very important to maintain company performance which ultimately affects the performance of stock returns. This can give confidence to investors to own the LQ45 company shares so that they can increase stock returns. The results of this study are not in line with the research conducted by Kusumo and Mutmainah (2010) and Wardana, et al. (2015) who found that the current ratio has no effect on abnormal returns. The results of this study are in line with the results of research by Septiana and Wahyuati (2016), which found that partially showing the debt equity ratio, the current ratio has a significant effect on stock returns.

Debt Equity Ratio (DER) partially determines stock returns. The higher the DER, the greater the dependence of the LQ45 company on outsiders so that the level of the company's risk is greater in meeting its debts, namely paying the principal of debt plus the interest. This has an impact on the decline in stock prices and stock returns, so that investors are not responsive to this information in making investment decisions on stocks. The results of this study are in line with the results of research by Septiana and Wahyuati (2016), which found that partially showing the debt equity ratio, the current ratio has a significant effect on stock returns. This study is not in line with the research of Kusumo and Mutmainah (2010), who found that the financial ratio on the Debt Equity Ratio (DER) has no significant effect on stock returns. Dividend Payout Ratio (DPR) partially determines stock returns. The higher the DPR, the better the stock return. LQ45 companies that have a high DPR of course cause the value of their share prices to increase because investors have better 
certainty about dividend distribution on their investment. This increase also raises the amount of demand for these shares, which also increases stock prices and has an impact on positive returns. Dividend Yield (DY) partially determines stock returns. The high DY of the LQ45 company indicates that a capital market is in an undervalued state, that is, if the stock market price is less than its fair value, then the shares must be bought and temporarily held, with the aim of obtaining capital gains if the price starts to rise later. The power that DY can predict comes from the role of dividend policy in distributing the returns obtained by the LQ45 company to shareholders.

Partial Earning Per Share (EPS) cannot determine stock returns. The factor of earnings per share (EPS) or earnings per share of the LQ45 company should have a strong influence on returns. The greater the value of earnings per share owned by the LQ45 company should be able to benefit its shareholders, besides that it means the company is also able to generate large amounts of profit. The results indicate that the company does not use EPS to determine stock returns. The results of this study are in line with research by Nuryana (2013), which found that EPS affects stock returns.

Partially Price Book Value (PBV) cannot determine stock returns. The relationship between the stock market price and the book value per share can also be used as an alternative approach to determining the value of a share, because theoretically, the stock market value must reflect its book value. The results indicate that the company does not use PBV to determine stock returns. This study is in line with the research of Wardana et al. (2015) who found that NPM, PBV and CR had no effect on abnormal returns.

Price Earning Ratio partially determines stock returns. Price earning ratio shows the amount of price per one rupiah earnings of the company. The lower the price earning ratio, it can be said that a stock is good as an investment choice. Meanwhile, the higher the price earning ratio indicates that the ratio of share price to the ability to earn profits is not appropriate. A lower PER ratio can lead to an increase in the company's LQ45 stock price, which means that the return will also increase, and vice versa. This research is in line with research conducted by Farkhan and Ika (2012), who find it is found that Price Earning Ratio (PER) has a significant effect on stock returns.

Return on assets partially determines stock returns. The higher the value of return on assets LQ45 shows that the capital invested by the company in all its assets produces a higher net profit. Conversely, if the value of return on assets is small, it means that the investment made by the company in its assets is less profitable. So the higher this ratio indicates the efficiency of asset management, which means management efficiency. This research is in line with research conducted by Farkhan and Ika (2012), who found that Return On Assets (ROA) has a significant effect on stock returns. This study is not in line with the research of Gunawan and Jati (2013), which found that there was no significant effect of the ROA variable on stock returns.

TATO (Total Asset Turnover) partially determines stock returns. If sales are greater than total assets, the rate of return on profits or returns obtained by LQ45 companies will be high, because large sales reflect large profits for LQ45 companies. Conversely, if the total assets are higher than the sale, the return will be low. This study is not in line with research conducted by Farkhan and Ika (2012), who found that TATO does not have a significant effect on stock returns.

\section{Conclusion}

In general, this study aims to synthesize whether the current ratio, equity ratio, dividend payout ratio, dividend yield, earnings per share, price book value, return on assets and total asset turnover are partially determinants of stock return variability. The population in this study were noncompanies banks that are included in the LQ45 according to a circular number: Peng-00028 / BEI.OPP / 01-2018 dated January 25, 2018. Nonbank companies are chosen because the types of products produced are not in the form of services. Hypothesis testing uses multiple linear regression analysis test tools.

After analyzing the data, several conclusions can be drawn, namely: only the current ratio, equity ratio, dividend payout ratio, dividend yield, return on assets and total asset turnover partially determine stock returns.

\section{References}

[1] Amarjit Gill, Nahum Biger, Neil Mathur. 2010. The Relationship Between Working Capital Management And Profitability. Business and Economics Journal. JSE Vol10.

[2] Dimitrich, Mohammad Bella Seantikerana and, Imron Rosyadi, S.E., M.Si. (2016) Analysis of the Effect of Financial Performance on Stock Returns in Lq 45 
Index Companies Listed on the Indonesia Stock Exchange for the 2010-2014 Period. Thesis, Muhammadiyah University of Surakarta.

[3] Fahmi, Irham. 2015. Analysis of Accounting Reports. Bandung: ALFABETA

[4] Farkhan and Ika. 2012. The Effect of Financial Ratios on Stock Returns of Manufacturing Companies in the Indonesia Stock Exchange (Case Study of Manufacturing Companies in the Food And Beverage Sector).

[5] Gunawan, I Putu Ari and I Ketut Jati. 2013. The Effect of Financial Ratios on Stock Returns in Making Investment Decisions on Leading Shares Listed on the Indonesia Stock Exchange. Journal of Accounting at Udayana University. Volume 2. No.1

[6] Hadiningrat, Ellia, Maryam Mangantar and Jessy Pondaag. Analysis of the Effect of Liquidity Ratios and Profitability Ratios on Stock Returns at LQ 45 Companies. Journal of EMBA Vol.5 No.2 June 2017, Hal. 2349 2357.

[7] Harahap, S.S., 2015. Critical Analysis of Financial Statements, Jakarta, Raja Grafindo Persada

[8] Harmono. 2014. A balanced scored based financial management. Jakarta: PT Bumi Aksara.

[9] Hidayat Taufik. 2010. The Effect of Liquidity Ratios, Solvency Ratios, Activity Ratios, Profitability Ratios, Market / Valuation Ratios on Stock Returns in Companies Listing on the Indonesia Stock Exchange. University of North Sumatra Thesis.

[10] Jogiyanto Hartono. 2011. Portfolio Theory and Investment Analysis. Seventh Edition. Yogyakarta: BPFE.

[11] Cashmere. 2016. Financial Statement Analysis. Jakarta: PT. Raja Grafindo Persada.

[12] Kheradyar, S, et al. 2011. Stock Return Predictability with Financial Ratios. International Journal of Trade, Economics and Finance, Vol. 2 No. 5

[13] Kusumo, RM Gian Ismoyo and Siti Mutmainah. 2010. Analysis of the Influence of Financial Ratios on Stock Returns in NonBank Companies. Diponegoro University

[14] Harahap, Sofyan Syafri. 2015. Critical Analysis of Financial Statements. Jakarta: RajaGrafindo Persada.
[15] Nuryana Ida. 2013. The Influence of Financial Ratios on LQ 45 Company Stock Returns on the Jakarta Stock Exchange. Journal of Actual Accounting, Vol. 2, Number 2, June 2013, p. 57-66

[16] Rismansyah. 2015. The Effect of Financial Ratios on Stock Returns in Property and Real Estate Companies Listed on the Indonesia Stock Exchange (BEI). Wahana Ekonomika Media Journal, Vol. 12, No.3, October 2015: $80-95$

[17] Sartono, A. 2009. Financial Management: Theory and Application, Fourth Edition, First Edition, BPFE Faculty of Economics UGM, Yogyakarta.

[18] Septiana, Farda Eka and Wahyuati, Aniek. 2016. The Effect of Financial Ratios on Stock Returns in Manufacturing Companies. Journal of Management Science and Research. Vol. 5, No. 1, ISSN: 2461-0593.

[19] Septiyuliana, 2016, The influence of intellectual capital and disclosure of intellectual capital on the value of companies conducting the initial public offering, 18th National Accounting Symposium, University of North Sumatra, Medan 16-19 September 2015

[20] Sugiyono. 2013. Administrative Research Methods. Bandung: CV Alfabeta.

[21] Sujarweni, V. Wiratna. 2017. Financial Statement Analysis: Theory, Application, \& Research Results. Yogyakarta: New Library Press.

[22] Sutrisno. 2009, Financial Management Theory, Concepts and Applications, First Edition, Prints. Seventh, Ekonisia Publisher, Yogyakarta.

[23] Tandelilin, Eduardus. 2011. Portfolios and Investments (theory and application). First Edition. Yogyakarta: Kanisius.

[24] Tryfino. 2009. Smart Ways to Invest in Stocks. Jakarta: Transmedia Pustaka.

[25] Wardana Guntur Kusuma, Tatang Ary Gumanti, and Elok Sri Utami. 2015. The Effect of Financial Performance on Stock Returns in the Jakarta Islamic Index Group Company. The University of Jember Repository.

[26] Wijesundera, A. A. V. I. et al. 2015. Predictability of Stock Returns Using Financial Ratios: Empirical Evidence from Colombo Stock Exchange. Kelaniya Journal of Management, Vol. 4 No. 2, JulyDecember 2015 